\title{
The Largetooth Sawfish, Pristis pristis (Linnaeus, 1758), is not extirpated from Peru: new records from Tumbes
}

\author{
Alejandra Mendoza, ${ }^{1}$ Shaleyla Kelez, ${ }^{1}$ Wilmer Gonzales Cherres,${ }^{2}$ Rossana Maguiño ${ }^{1}$ \\ 1 ecOceánica, Copernico 179, San Borja, Lima 41, Peru. 2 Asociacion de Pescadores Artesanales para Consumo Humano Directo de La Cruz, \\ Caleta La Cruz, Tumbes, Peru. \\ Corresponding author: Alejandra Mendoza, alejandra.mendoza@ecoceanica.org
}

\begin{abstract}
The Largetooth Sawfish, Pristis pristis, was for a long time considered extirpated from Peru. However, here we report the capture of 2 individuals from the north coast of Peru, indicating that this species is still extant in Peruvian waters. Both individuals were adult-sized and their encounters occurred during the austral summer, which could indicate a seasonal presence in those waters. Gillnets are still a major threat for the species as both specimens were incidentally captured with this gear. Our finding highlights the need for continuous research, awareness, and legal protection of this species.
\end{abstract}

Key words

Tropical Eastern Pacific; bycatch; Pristidae; northern Peru; critically endangered species.

Academic editor: Arturo Angulo Sibaja | Received 15 March 2017 | Accepted 24 May 2017 | Published 4 August 2017

Citation: Mendoza A, Kelez S, Cherres WG, Maguiño R (2017) The Largetooth Sawfish, Pristis pristis (Linnaeus, 1758), is not extirpated from Peru: new records from Tumbes. Check List 13 (4): 261-265. https://doi.org/10.15560/13.4.261

\section{Introduction}

All extant sawfishes belong to the family Pristidae, which includes the genera Anoxypristis White \& MoyThomas, 1941 and Pristis Linck, 1790 (Compagno and Cook 1995). The genus Anoxypristis only has 1 species: the Knifetooth Sawfish, Anoxypristis cuspidata (Latham, 1794); the genus Pristis includes 4 species: Largetooth Sawfish, Pristis pristis (Linnaeus, 1758); Smalltooth Sawfish, Pristis pectinata Latham, 1794; Dwarf Sawfish, Pristis clavata Garman, 1906); and Green Sawfish, Pristis zijsron Bleeker, 1851 (Faria et al. 2013).

Sawfishes live in shallow coastal waters usually at depths up to $20 \mathrm{~m}$ but as deep as $122 \mathrm{~m}$ (Harrison and Dulvy 2014). They can tolerate wide ranges of salinity and thus can be found in continental waters and estuaries.
For example, they can swim far up into large rivers and have been found in lakes in South America, Africa, and Southeast Asia (Harrison and Dulvy 2014).

Pristis pristis is morphologically characterized by the first dorsal fin located in front of the origin of the pelvic fins, the presence, in all stages of growth, of the lower lobe of the caudal fin, and by having a shorter and wider rostrum than the other species of Pristis (Faria et al. 2013). Recent studies have shown that $P$. perotteti from the Atlantic Ocean and P. microdon from the western Indo-Pacific Ocean are synonyms of $P$. pristis. This eurohaline species, as currently defined, has a circumtropical geographic distribution with 4 genetically differentiated populations: eastern Pacific, western Atlantic, eastern Atlantic, and western Indo-Pacific Ocean (Faria et al. 2013). 


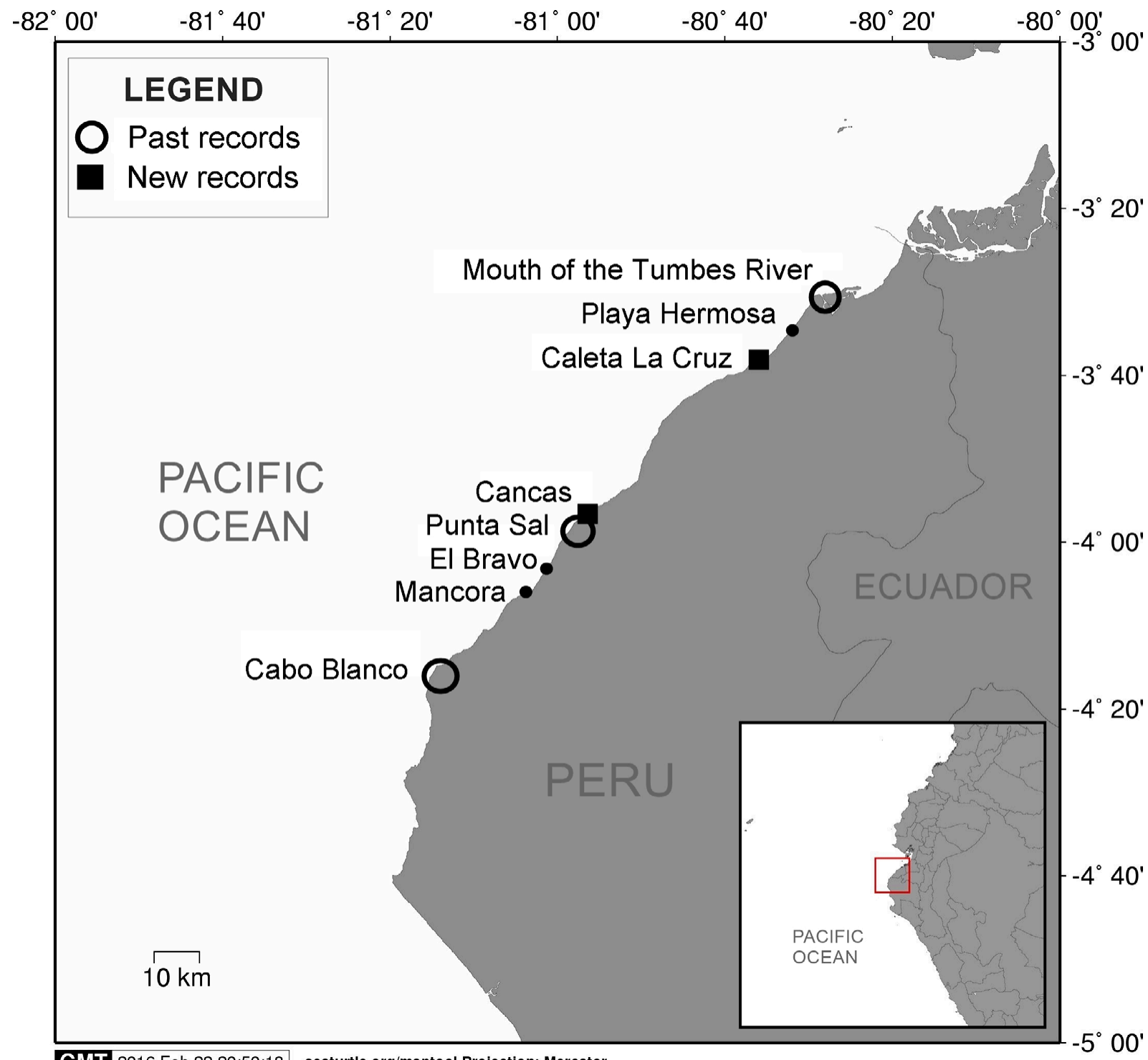

GMT 2016 Feb 22 20:50:18 seaturtle.org/maptool Projection: Mercator

Figure 1. Map showing the locations of Pristis pristis recorded in Peru. Circles are previous reports of landings: mouth of the Tumbes River (Chirichigno and Cornejo 2001), Punta Sal and Cabo Blanco (McDavitt pers. comm. 2016). Squares show new landing reports: Caleta La Cruz (2014) and Cancas (2015), both in the Department of Tumbes. Map created using Maptool (Seaturtle.org 2002).

Apparently, populations of $P$. pristis have been reduced considerably from their former abundances throughout their range (Carlson et al. 2013a). According to Carlson et al. (2013a), the eastern Pacific population was formerly distributed from the Gulf of Mexico to Peru, but until 2013 only a few records existed from the Pacific coast of Nicaragua, Panama and Colombia. Therefore, Carlson et al. (2013a) argued that there had been a considerable population decline based on the retraction of the extent of occurrence of $\geq 80 \%$ over a 3 -generation period. A major threat to P. pristis in the eastern Pacific is the decline of mangrove habitats that are utilized as nurseries, for reproduction, and feeding grounds. Other pervasive threats are longline fisheries for sharks and coastal gillnets (Carlson et al. 2013a). Consequently, the International Union for Conservation of Nature listed this species and all other sawfish species as Critically Endangered (Kyne et al. 2013). Pristis pristis is also included in Appendix 1 of the Convention on International Trade in
Endangered Species of Wild Fauna and Flora, as well as in Appendix 1 of the Convention on the Conservation of Migratory Species of Wild Animals (CMS).

In Peru, occurrence data on sawfishes are relatively scarce. Until 1920, P. pristis was not reported in Peru, but Nichols and Murphy (1922) mentioned that fishermen already knew of it there. Chirichigno and Cornejo (2001) listed the genus Pristis from Peruvian waters and reported 2 species: P. microdon and Pristis pectinatus (a synonymous of $P$. pectinata). Chirichigno and Cornejo (2001) mentioned that both of these species occur in Tumbes, northern Peru; however, the report of P. pectinatus by Chirichigno and Cornejo (2001) was likely a misidentification of $P$. pristis, because we now know that P. pectinata only occurs in the Atlantic Ocean (Carlson et al. 2013b). In addition, there is undated photographic evidence showing sawfish specimens captured in Cabo Blanco and Punta Sal (Fig. 1) (Dr Matthew McDavitt pers. comm.). The most recent reports for Pristis species 
in Peru come from information collected by researchers from the Instituto del Mar del Peru between 1996 and 2005 in the Tumbes Region (Llanos et al. 2010), but these reports are without specific information. However, an author of this report (Carlos Inga, pers. comm.) mentioned that sawfish remains were observed only up to the 1990s.

Nonetheless, until a decade ago the international scientific community thought that sawfishes did not occur in Peru (Compagno and Cook 1995, Compagno and Cook 2005). Following Faria et al. (2013), who included P. pristis from Peru based on previous works listing the species in Peruvian waters, subsequent scientific and technical publications also listed this species from Peru but without more precise distributional data and cited it as a historical distribution given the absence of confirmed records for more than 10 years. As a result, many researchers believed that the species had been extirpated from Peru (Carlson et al. 2013a, Dulvy et al. 2014, Harrison and Dulvy 2014).

According to fishermen from Cancas and Caleta La Cruz (Fig. 1), sawfishes used to be abundant along the north coast of Peru, but due to overfishing, they have now almost disappeared. Overfishing was driven by the high valued in Peru of sawfish teeth using in cockfighting as artificial spurs fitted to the birds' feet as a competitive advantage during fights (McDavitt 2014). In addition, sawfishes are not protected by the Peruvian legislation, so the capture and commercialization of this species is not illegal.

The objective of this study was to update the presence of $P$. pristis in Peru by reporting 2 recent records.

\section{Methods}

The area of interest is located along the coast of the department of Tumbes (Fig. 1), in the Guayaquil ecoregion of the Tropical East Pacific Marine Province (Spalding et al. 2007). The coastline of Tumbes includes 2 mangrove systems that are fed by the waters of the Tumbes and Zarumilla rivers (Angulo 2014).

On 22 January 2014, 1 specimen of $P$. pristis was incidentally captured in our nets during commercial fishing (by Wilmer Gonzales Cherres) and taken to the landing site at La Cruz, Tumbes (Fig. 1, Table 1). The sawfish was caught at dawn with a gillnet off Playa Hermosa. It was later butchered and its teeth were sold (Table 1). This specimen measured approximately $350 \mathrm{~cm}$ in total length (TL), the rostrum $100 \mathrm{~cm}$, and the body without rostrum weighed $146 \mathrm{~kg}$ (Fig. 2). The specimen was a gravid female, containing yellow and spherical eggs similar to those of the Pacific Angel Shark, Squatina californica Ayres, 1859.
On 14 February 2015 (9:00 h), we received a call from a fishermen informing us that a sawfish was being brought alive to the Cancas dock in the district of Canoas de Punta Sal, Tumbes (Fig. 1, Table 1). The first author moved to the site and at 11:00 $\mathrm{h}$ the boat arrived with the specimen. It measured approximately $6 \mathrm{~m}$ TL, but the sex could not be determined (Fig. 3). The fish was incidentally caught by the boat during a gillnet fishing trip in front of El Bravo beach (Fig. 1). Once at the dock, fishermen Richard Pingo Antón, Luis Pingo Antón, Baltazar Fiestas Querevalu, and Tomas Pingo Chiroque called the authorities to decide what to do with the sawfish since they were unfamiliar with the regulation on its capture, but they knew that it was a rare find. They decided to release the individual, which was carried out in the presence of the Director of the Regional Directorate of Production of Tumbes (DIREPRO Tumbes), a representative of the General Directorate of Coast Guard (DICAPI), and A. Mendoza, a representative of our nonprofit organization ecOceánica, all who signed the Act of Liberation drafted by DIREPRO Tumbes. The individual was released at 12:40 $\mathrm{h}$ on the same day.

\section{Results}

Both specimens were identified as $P$. pristis (Figs. 2, 3) based on the following combination of distinctive characters: origin of the first dorsal fin anterior to the pelvic fin origin and presence of a lower caudal fin lobe (Faria et al. 2014). The specific identification of the specimens also was confirmed using photographs by the sawfish specialist Dr Peter Kyne, from Charles Darwin University.

\section{Discussion}

In Peru, the last year that sawfishes were observed was 1999 (Carlos Inga pers. comm.). Since then, a couple of publications reported the presence of sawfishes in Peru based on Chirichigno and Cornejo (2001). The National Action Plan for the Conservation and Management of Sharks, Rays and Related Species in Peru (PRODUCE 2014) mentions 2 species of Pristidae but without

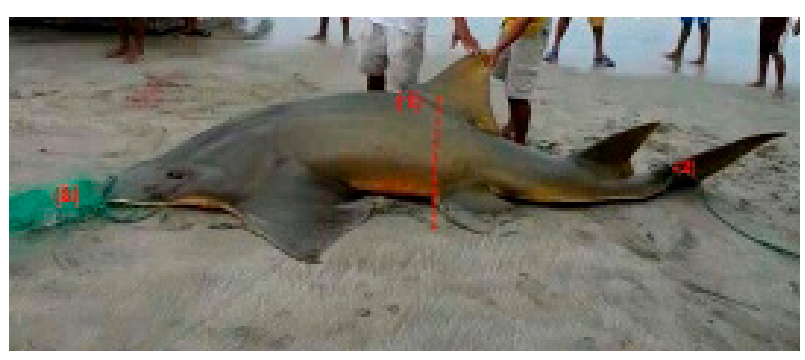

Figure 2. Sawfish landed dead at La Cruz, Tumbes, on 22 January 2014.

Table 1. New records of Pristis pristis in Peru including capture data and the fate of the individuals.

\begin{tabular}{lllllll}
\hline Date & Landing site & Latitude & Longitude & Size TL cm & Sex & Fate \\
\hline January 22, 2014 & La Cruz, Tumbes & -3.6362 & -80.5996 & 350 & female & Dead, teeth sold \\
February 14, 2015 & Cancas, Tumbes & -3.9445 & -80.9400 & 600 & unknown \\
\hline
\end{tabular}



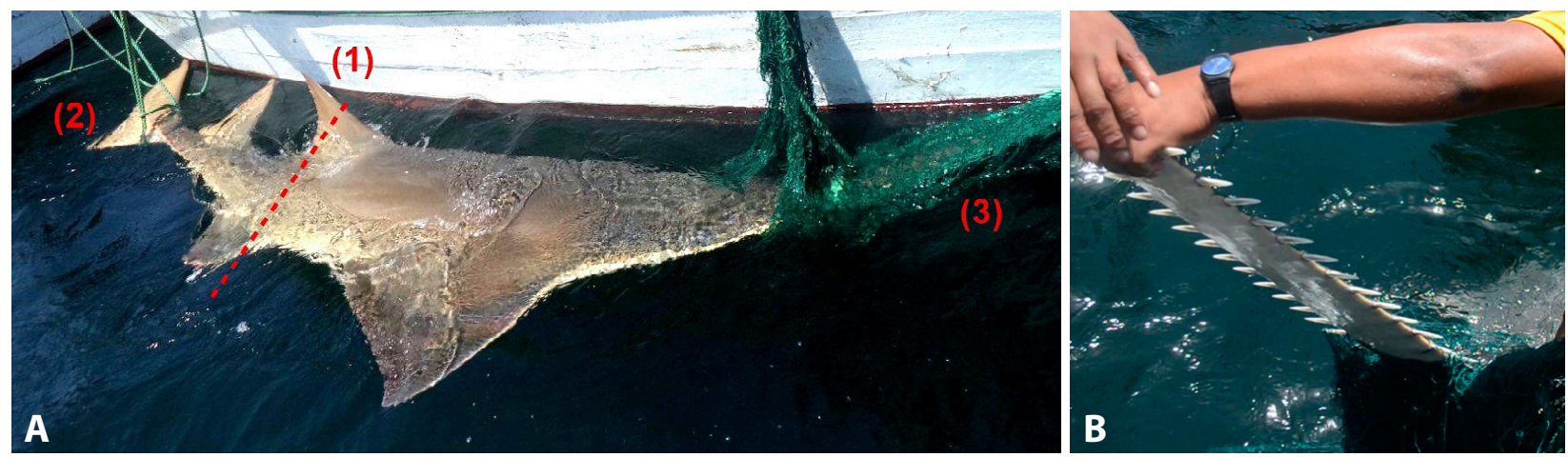

Figure 3. Sawfish captured on 14 February 2015, taken alive to Cancas, Tumbes and later released. A. Entire specimen showing (1) dorsal fin anterior to the origin of the pelvic fins, (2) the caudal fin, and (3) the rostrum. B. Another view of the rostrum.

specifying them. The other publication is a revised list of Chondrichthyans in Peru (Cornejo et al. 2015), which included $P$. pristis and P. pectinata. Given that the inclusion of this species in PRODUCE (2014) and Cornejo et al. (2015) are the result of literature reviews and are not based on field surveys, the documentation here of 2 new specimens provide the first empirical records of $P$. pristis in Peru since 1999.

These records demonstrate that $P$. pristis is not extirpated from Peru, and they highlight the need to identify and protect critical habitats that could contribute to sawfish conservation. There is additional anecdotal information. On 2 March 2017, a new specimen was captured in a gillnet and landed dead in Mancora (J. Guerrero Chinchay, Mancora Dock Manager, pers. comm). The 3 reports of P. pristis are from the same area where Chirichigno and Cornejo (2001) had earlier reported it (Fig. 1). The spatial distribution of this species in Peru would seem to extend from the Ecuadorian border to Cabo Blanco (Fig. 1).

The capture of a specimen of P. pristis in the Pacific waters of southern Ecuador was also reported in July 2014. The individual (506 cm TL) was landed in the port of Santa Rosa de Salinas (Universidad Laica Eloy Alfaro de Manabi 2014). This record shows that this species is not extirpated from Ecuador either, and would suggest that there is still a small extant population between southern Ecuador and northern Peru, an area where river mouths form mangrove estuaries. These data, coupled with previous reports from Nicaragua, Panama and Colombia (Carlson et al. 2013a) give support to the premise that the distribution of this species is continuous from northern Peru to Nicaragua.

The size at sexual maturity of $P$. pristis is $300 \mathrm{~cm}$ for females and 280-300 cm for males (Dulvy et al. 2014). Therefore, the 2 observations in Peru, and 1 in Ecuador, suggest that this part of the Eastern Pacific, adjacent to mangroves, is used by adults and reproductively active females. Moreover, it is possible that the better-preserved mangrove habitats of northern Peru could be preferred by sawfish in the southeast Pacific. On the other hand, the seasonality of the 3 encounters in Peru (late January to early March) may imply that the presence of this species in Peru represents a seasonal migration from its core area in Central America as postulated by Kyne et al. (2014). However, the observation in July of the individual in Ecuador is not in agreement with the seasonal migration hypothesis. In this regard, more research is needed to understand the habitat use and phenology of this species.

Gillnets are a major threat to the survival of sawfishes as all 3 individuals recorded recently in Peru were captured using this gear. As we have observed in the field, many fishers in northern Peru set their nets at night and check them in the morning, leaving them long periods unattended. This practice can have deleterious collateral impacts as they capture non-target species that will likely drown, be depredated, or suffer post-release mortality from stress.

Now that $P$. pristis is conclusively known not to be locally extinct in Peru, there is a need for further research on this species, to put the sawfish on the agenda of the Peruvian government, to promote their conservation through environmental education, and to seek national legislation to give the species full legal protection.

\section{Acknowledgements}

To the fishermen from Cancas: Richard Pingo Antón, Luis Pingo Antón, Baltazar Fiestas Querevalu, and Tomas Pingo Chiroque for liberated the specimen found in front of Playa Hermosa. To Dr Matthew T. McDavitt for the historic photographic material. To Dr Peter Kyne for the verification of the specimens as Pristis pristis and for providing literature. To Lisa E. Poser and Catherine M. McClellan for providing edits that improved the manuscript.

\section{Authors' Contributions}

AM, WGC and RM collected the data, AM and SK wrote the text.

\section{References}

Angulo F (2014) Los manglares del Perú. Xilema 27: 5-9.

Carlson J, Smith K, Kyne PM (2013a) Pristis pristis (Eastern Pacific subpopulation). The IUCN Red List of Threatened Species 2013: e.T43508949A43508976. https://doi.org/10.2305/iucn.uk.2013-1. 
rlts.t43508949a43508976.en. accessed on: 2016-1-22.

Carlson J, Wiley T, Smith K (2013b) Pristis pectinata. The IUCN Red List of Threatened Species 2013: e.T18175A43398238. http:// dx.doi.org/10.2305/iucn.uk.2013-1.rlts.t18175a43398238.en. Accessed on: 2016-1-22.

Chirichigno N, Cornejo M (2001) Catálogo Comentado de los Peces Marinos del Perú. Informes del Instituto del Mar del Perú. IMARPE, Callao, 314 pp.

Compagno LJV, Cook SF (1995) The exploitation and conservation of freshwater elasmobranchs: status of taxa and prospects for the future. Journal of Aquariculture and Aquatic Sciences 7: 62-90.

Compagno LJV, Cook SF (2005) Order Rajiformes, batoids, suborder Pristoidei, sawfishes. In: Fowler SL, Cavanagh RD, Camhi M, Burgess GH, Cailliet GM, Fordham SV, Simpfendorfer CA, Musick JA (Eds) Sharks, Rays and Chimaeras: the Status of the Chondrichthyan Fishes. Status Survey. IUCN/ SSC Shark Specialist Group, Gland, 320-328.

Cornejo R, Velez-Zuazo X, Gonzalez-Pestana A, Kouri C, Mucientes GR (2015) An updated checklist of Chondrichthyes from the southeast Pacific off Peru. Check List 11 (6): 1809. https://doi. org/10.15560/11.6.1809

Dulvy NK, Davidson LN, Kyne PM, Simpfendorfer CA, Harrison LR, Carlson JK, Fordham SV (2014) Ghosts of the coast: global extinction risk and conservation of sawfishes. Aquatic Conservation: Marine and Freshwater Ecosystems 26 (1): 134-153. https://doi. org/10.1002/aqc. 2525

Faria VV, McDavitt MT, Charvet P, Wiley TRR, Simpfendorfer CA, Naylor GJP (2013) Species delineation and global population structure of Critically Endangered sawfishes (Pristidae). Zoological Journal of the Linnean Society 167:136-164. http://doi.org/b94r

Faria VV, McDavitt MT, Charvet P, Wiley TRR, Simpfendorfer CA, Naylor GJP (2014) Taxonomy: How many sawfish species are there? In: Harrison, LR, Dulvy NK (Eds) Sawfish: A Global Strategy for Conservation. International Union for the Conservation of Nature Species Survival Commission's Shark Specialist Group, Vancouver, 22-25.

Harrison LR, Dulvy NK (Eds) (2014) Sawfish: A Global Strategy for
Conservation. International Union for the Conservation of Nature Species Survival Commission's Shark Specialist Group, Vancouver, $113 \mathrm{pp}$.

Kyne PM, Carlson J, Smith K (2013) Pristis pristis. The IUCN Red List of Threatened Species 2013: e.T18584848A18620395. http:// dx.doi.org/10.2305/iucn.uk.2013-1.rlts.t18584848a18620395.en. Accessed on: 2016-1-22.

Kyne PM, McDavitt MT, Graham RT (2014) Eastern Pacific Ocean. In: Harrison LR, Dulvy NK (Eds) Sawfish: A Global Strategy for Conservation. International Union for the Conservation of Nature Species Survival Commission's Shark Specialist Group, Vancouver, 68.

Llanos J, Inga C, Ordinola E, Rujel J (2010) Investigaciones Biológico Pesqueras en la Región Tumbes, Peru. 1996-2005. Informe Instituto del Mar del Perú 37: 95-113.

McDavitt MT (2014) Sawfish products and trade. In: Harrison LR, Dulvy NK (Eds) Sawfish: A Global Strategy for Conservation. International Union for the Conservation of Nature Species Survival Commission's Shark Specialist Group, Vancouver, 72-75.

Nichols JT, Murphy RC (1922) On a collection of marine fishes from Peru. Bulletin American Museum of Natural History 46: 501-516. http://hdl.handle.net/2246/1927

PRODUCE (2014) DS 002-2014-PRODUCE. Aprueban el Plan de Acción Nacional para la Conservación y Ordenamiento de Tiburones, Rayas y Especies Afines en el Perú (PAN Tiburón - Perú).

Seaturtle.org (2002) Maptool. Seaturtle.org, Inc. http://www.seaturtle. org/maptool/. Accessed on: 2017-2-10.

Spalding M, Fox H, Allen G, Davidson N, Ferdaña Z, Finlayson M, Halpern B, Jorge M, Lombana A, Lourie S, Martin K, McManus E, Molnar J, Recchia C, Robertson J (2007) Marine ecoregions of the world: A bioregionalization of coastal and shelf areas. Bioscience 57 (7): 573-583. https://doi.org/10.1641/b570707

Universidad Laica Eloy Alfaro de Manabi (2014) El Pez Sierra considerado extinto en las aguas de Ecuador reaparece en el Puerto Pesquero de Santa Rosa de Salinas. Universidad Laica Eloy Alfaro de Manabi. http://www.uleam.edu.ec/el-pez-sierra-consideradoextinto-en-las-aguas-de-ecuador-reaparece-en-el-puerto-pesquerode-santa-rosa-de-salinas/. Accessed on: 2017-02-10. 